\title{
Adolescents without Adolescence: Reflections on Adolescents' Formation of Subjectivity and Their Families in a Neoliberal Context
}

\author{
Alejandro Klein \\ Universidad de la Republica (Uruguay)
}

\begin{abstract}
This study seeks to determine how certain social situations cannot help but influence subjectivity and family ties. The Keynesian age encouraged and promoted a relatively stable socioeconomic matrix based on a probable future and achievable promise. The installation of a family model related to protective parents who were capable of caring for and protecting their children has been observed. Adolescent subjectivity is constructed based on parameters like generational confrontation and growth, and happiness before the possibility of exercising autonomy. On the other hand, neoliberalism produces a "retraction" of social spaces, dismisses the future, and feelings of instability and insecurity are prevalent, making the family model a "structure that overwhelms parents." Adolescent subjectivity seems incapable of executing generational confrontation, predominantly showing a desire to "protect" the family ("exacerbated messiah complex") by means of a fantasy that acts as a "threading scene" capable of annulling the search for autonomy and growth.
\end{abstract}

Keywords: parents, adolescence, threading scene, neoliberalism

\begin{abstract}
Este trabajo busca puntualizar cómo determinadas situaciones sociales no pueden dejar de incidir en la subjetividad y los vínculos familiares. La modernidad keynesiana alentaba y proponía una matriz socioeconómica que era relativamente estable, con instauración de un porvenir probable y declaración de una promesa alcanzable. Se puede observar la instauración de un modelo familiar relacionable a la experiencia de padres amparadores, capaces de cuidar y proteger. Desde allí la subjetividad adolescente se construye desde parámetros como los de confrontación generacional, crecimiento y júbilo ante la posibilidad de ejercer autonomía. Por el contrario el neoliberalismo genera una "retracción" de espacios sociales, destitución del porvenir y predominio de sensaciones de inestabilidad e inseguridad que facilita la instauración de un modelo familiar que denomino "estructura de padres agobiados". La subjetividad adolescente aparece incapaz de ejercer confrontación generacional, predominando el deseo de "proteger" a la familia ("mesianismo exacerbado") a través de una fantasmática que actúa como "escena de enhebramiento" capaz de anular la búsqueda de autonomía y crecimiento.

Palabras clave: padres, adolescencia, escena de enhebramiento, neoliberalismo
\end{abstract}

Correspondence concerning this article should be addressed to Dr. Alejandro Klein, Facultad de Psicología- Montevideo- Uruguay, José Benito Lamas, 2815-Montevideo-Uruguay. Phones: (005982) 7080353 and (005521) 80035112. E-mail: alejandroklein@hotmail.com

How to cite the author of this article: Klein, A 
This study seeks to make a contribution to the subject of the relationship between Subjectivity, Culture and Society, trying to see how adolescents' subjectivity and families are negotiated within the modern, Keynesian, welfare state, and how changes implicated in neoliberalism are verified in selfexpression and self-development. For both situations, certain elements will be analyzed that influence how an adolescent identifies and expresses him or herself during the construction of subjectivity.

The hypothesis I am working from is that social context, the construction of subjectivity and relationships are largely interrelated and inevitably exercise a mutual influence over each other. Along those lines, I am currently investigating what bearing these social phenomena have on how we relate to one another. This implies that there is no single, generalized, unchanging subjectivity. There are subjectivities and processes of subjectification, which makes research dealing with those aspects imperative.

It would be impossible to go into depth on every topic implicated in social and economic neoliberalism due to space limitations. I will simply say that certain characteristics of neoliberalism, such as rising rates of structural unemployment, reduced salaries, an extremely flexible work day, alarming rates of drop-out among students, and radicalized processes of social exclusion, cannot help but affect the family and its members.

It is a situation in which the community denies its foundation (Puget \& Kaës, 1991), provoking generalized violence both among and against its subjects. In this way, the narcissist contract (Aulagnier, 1975) is resented for affecting continuity, permanence and change.

Everyday life has become a matter of "survival," with slim to no opportunities in education and work. This coincides with an exhausted capacity for tolerance between family members, which I call in the present study the "structure of overwhelmed parents." The ability for young people to grow becomes fragile and the question becomes: to consume or not to consume, survival or extinction, eliminating the ability to protect "well enough." This study seeks to explain some of these urgent and stressful questions.

It is important to note that due to this paper's essay style, the clinical material is included exclusively for reference, not intending to act as empirical support. I am writing a thorough analysis of clinical material collected from adolescents in another publication (Klein, 2006).

\section{Keynesian Modernity: The Family, Parenting and Protection}

Giddens observes that the daily experience of security and safety is reduced to "certain experiences characteristic of infancy" (Giddens, 1991/1997, p. 92), related to the feeling of "basic trust": "trust not only implies that one has learned to trust in equity, equality and the continuity of external agents, but that one can trust in one's own self" (idem, p. 94).

This trust relates to the experience of protective parents, capable of caring for and protecting their children. This extends into the child's social development. If a child learns to trust in his or her parents, it is because they also trust their environment and vice versa. There is a continuous structure, then, between the family, social, and subjective spheres- intimately related to one another - that establishes signs of trust and experiences of safety and reassurance.

This special union is a success and an expression of modernity, one of whose greatest manifestations is achieving "basic trust." Giddens (1991/1997) explicitly relates this process to the quality and the type of care that provides the individual needs of the child. This care simultaneously expresses certain values and cultural codes to be reproduced and valued by the child.

One condition of basic trust is that there be a sense of integration between one's parents and the social sphere, or in other words, between the parents and the adulthood they possess. The transmission of certain models of fatherhood and motherhood solidly and firmly reflect what it is to be an adult within a Keynesian society. Parents who teach "basic trust" are proud to be parents.

It is necessary, then, to keep in mind the social structures that dignify parents as adults in order to enable that feeling. Teaching children this way, in effect, transmits society through activities during which adults identify and dignify themselves. To be an adult, to educate, and to be integrated into society, is a self-fulfilling triad:

Part of the humanization of a father is his transition to emotional reality on his own terms, the movement from a workrelated space into home life (...). The relationship between the family and the father-other, and the nature of his transformation into a young father, are of considerable psychic importance to the growing child. To a certain extent, it is an essential job that helps build the relationship of the child with reality (Bollas, 1991, p. 207).

The home-work dynamic, a precise education and the increased security that society expects of adults, just as adults provide during their children's infancy, are all transmitted to the dimension of pride:

He (the father) adapts to the law of the passage of time, which distances and separates family members from the home sphere. Fathers who accept this transition are transported to another place, to the world of work and obligations (...) The return of the father from work is therefore a complex, intrapsychic moment for the child awaiting him, for the wife who perhaps needs to process the transition, too, and for the man himself (...) Inevitably, every child comes to realize that there exists a world that makes their history, and that runs on its own time, beyond the walls of the home (Bollas, 1991, p. 218).

That is to say, children are not only raised on narcissism, but also believing that some of what they are given will 
serve them in their lives and in their futures. The family becomes a component of the narcissist contract, capable of anticipating and cathecting a possible future, and giving it a sense of cohesiveness and unity.

Giddens (1991/1997) explains the importance of primary unity, arguing that not dividing family members is not in and of itself Oedipal, but rather a model for psychosomatic and social integration. In any case, it is not an Oedipus scenario in the sense of rivalry, but rather in terms of intergenerational cooperation (Kohut, 1982).

From this perspective, what prevail in the family relationship are real, not fantasized, experiences, through which the child is empowered by what the father teaches him or her, and acts as a version of an expert system. At the same time, the absence of the parents is not experienced as a catastrophe because the feeling of basic trust always creates "space" between child and parents.

This potential space: "refers to the ability of the child to tolerate distance from their caregiver" (Giddens, 1991/1997, p. 95). "Potential" as a subjective and relationship operating system, complicates the nuclear family and comes as a consequence of the fact that, in modernity, the notion that distance from one's parents does not imply their extinction must be subjectively negotiated. This is produced by certain fractures that Giddens does not identify. One such fracture is that children are educated socially (at school) as well as by the family and another is that of the home sphere from the space of productivity and work.

In the Middle Ages (Ariès \& Duby, 1990a), the home sphere was also a space of economic productivity and education, a point of disassociation and contrast from modernity. Thus, in the construction of subjectivity, the potential or transitional space (Winnicott, 1979) seeks resolution of the father's absence as his potential to return. At the same time, a crucial homology occurs between the home -a closed space - and subjectivity - another closed space. Coming and going, leaving and entering, and receiving and transforming all complicate the psyche, while making sense of family dynamics. It is not in vain that Winnicott (1972) suggests one's ability to be alone as an index of mental health, in that it reveals a nucleus of psychological development of trust, one centered in the trust that the caregiver will return.

The nuclear family, then, is more than a simple division of roles between father, mother and children. It implies the specific operation of different spaces and times, reflecting many, specific types of subjectivity. The care giving "expert" is not only the person who cares for the child, but also the one who guarantees the necessary conditions of that child's survival. This demonstrates that between home, society and subjectivity there is not only integration but also a maintained expectation (prediction) of the caregiver's return at times when integration is absent (Giddens, 1991/1997).

This feeling of expectation is fundamental and indispensable to basic trust. I certainly believe that it demonstrates a consolidation of an unnecessary mental zone that reaches psychic representation in the form of something integrated into thought (Bollas, 1991).

Winnicott explains: "Good care produces a state of things in which integration becomes a fact and a person is said to exist" (Winnicott, 1979, p. 141). In other words, "sufficiently good" parental care is that which, in the first place, avoids the appearance of that which generally remains disperse, defending solid structures in exchange: the true self, the feeling of security, a state of integration and a state of continuity.

This zone of the mind is associated with the ability to imagine, or reflexive functioning, which denotes an understanding of one's own behavior and that of others in terms of mental states (Fonagy, 1999, 2000). Healthy attachment reflects the ability of parents to observe their children's mentality and facilitate in them a general understanding of mentality. I suggest, then, that we revise the notion of "basic trust" to consider it to involve the processes Green calls tertiary (Green, 1994). This would theorize the capacity to incorporate processes of attachment and detachment, and bring repressed feelings into consciousness, as integral to the psyche

Parents use reflexive functioning to transmit two pieces of information. First, that matters may be thought through and resolved, and second, that that process can be carried out in the child's mind. This places confidence in the child, while simultaneously transferring the harmony of a stable social context, indispensable in order for things to acquire a sense of rationality. This way, parents create the precedence for a value system for children to apply to thinking: "No thought is possible without the precedence of other thinkers, and the collective formations that came before the subject" (Kaës, 1994, p. 71).

In this way, one hopes that the child gradually takes on responsibilities, learning to respond to their environment with unsettled feelings or worries (Winnicott, 1979). I consider unsettling feelings an opportunity to explore new things, and it certainly involves what is called a "transformational scene" operating from the psyche and capable of sacrificing for change (Klein, 2003, 2004). The ability known as "worrying" can also begin in the reverse order; as Brandt, Giovacchini, and Lobel (1989) argue, if the mother is capable of worrying about her baby, she will consider her child an "other" and will tolerate his or her personal, transitional processes ${ }^{1}$.

We may think that adequate care giving techniques definitely involve abilities that allow one to achieve

1 In other words: this opposes endogamous fusion. 
autonomy, security in oneself, the ability to be alone, in other words, psychic traits that allow for the development of the process of citizenship with its implicit interplay of rights - obligations, limits and freedoms. In the case of citizenship, the theme of interlocutor - neighbor- is integral to its development. Similarly, in the origins of thinking, I propose the theme of similarity - fraternity as being of utmost importance (Kaës, 1994).

For this reason, a child should be able to use an object with "cruelty" (Winnicott, 1979), or rather, use it excessively, while at once maintaining a calm, tranquil relationship of mother -environment-. Lyons-Ruth (2004) proposes that the emotional unavailability of parents generates emotional vulnerability. In contrast, their emotional availability is related to the mother being prepared to be a mother, and to be used as such without restriction, while at the same time being recognized socially as a mother - adult without restriction and without being discredited as such.

Still, there remains another possible point of overlap between social and family organization. This refers to the prohibition of incest and patricide. This "great prohibition" (Kaës, 1993, p. 345) assures the survival of future generations and a sense of propagation and introduces the idea of transmission, of descendents and of the law as an essential regulator.

Thus, a common, shared, social ideal is configured: the passage of the original family to the destined family of the future. In terms of subjectivity, this involves elucidating ambivalence to create a base for emotional structure.

The classical father appears to be a regulator of desires and is a designated, "assigned" representative of the law (Aulagnier, 1975), expressing an isomorphism between symbolic laws and social norms: "as the capacity to connect (...) we desire an association with others that allows human spaces to exists" (Kaës, 1994, p. 193).

Along those lines, the Oedipus complex organizes and delineates the differences between sexes and generations, as well as temporal and subjective differences: the mother has to do with origins, narcissism, and the past, while the father is associated with objectivity, the future and successive generations (Aulagnier, 1975) ${ }^{2}$. The mother should - in this imaginary world - guarantee the origin and foundation of the future father and his exogamous success. Achieving the threat of castration implies a departure from the immortality of primary narcissism, and accepting the mortality implicit in secondary narcissism, as a means of recognizing oneself in the cycle of generations. When these conditions are present, access is granted to social recognition and to shared ideals.
Thus, in the Oedipus scenario, the reflexive structure and the ability to interact fuse when:

It is accepted that not only does the other desire him or her [the child], but also a third party; they are desired even when they are not the only one; they are desired for one thing and the third for another thing (...) the passage from a logic of exclusion to a conjunction -me and the third-it is not merely a question of guaranteed evolution over time...in the context of intersubjectivity in which the subject develops, messages from the meaningful other, the experiences of waiting, preferences and themes all leave their mark on this sensibility (Bleichmar, 1981, p. 11).

A process originates from there (Kaës, 1993) that defines the psyche and involves social renovation through ideals that pertain to a particular group and, at once, an emblem of belonging to that group. If the stress that surrounds primary narcissism is the stress of vulnerability (Bernard, 1991), surrounding the ideal is the stress of assignment. The subject, then, chooses certain values (through their Ideal Self), and assigns them to him or herself in order to feel like part of a group: "through this process, the subject is assured continuity, unity, and self-value" (Kaës, 1993, p. 349).

Through the Ideal Self, the subject demands to be considered a representative of the group, in a contract that assigns pre-established, preserved places with new meanings in order to enter into a symbolic discussion.

The Oedipus complex, then, both prohibits and liberates (Laplanche, 1980), restricts and enables and labels while structuring, in that it re-opens the cycle of exchanges that tie a family to the social sphere and vice versa. In this way, it ensures continuity between families, but a discontinuity within the family unit itself. Thus, the law of castration seems to be a "liberating phenomenon" (Laplanche, 1980, p. 155$).^{3}$

Nevertheless, in order for the threat of castration - the Oedipus axis - to have an effect, there must be a strong father, a father capable of carrying out that threat. Like the confrontation discussed by Winnicott (1972), the Oedipus complex requires differentiated, separate places for adults and for children, or better said, adults must want to be adults and not kids. This rests on a set structure of generational and familial roles.

The civilized option presented by modernity is to renounce the mother, or put her beneath the zone of what is prohibited and move on to another feminine object. This requires one to renounce what is maternal to access that which is feminine. However, that situation could also be read in terms of spatial and temporal coordinates, which try to "break" the maternal space in order to enter the temporal

\footnotetext{
2 I am aware of the gender prejudices involved in Aulagnier's way of presenting the matter.

3 In a sense, I ask myself what a child might understand of the Oedipus complex. I do not believe that it is the order of understanding that comes into play here. Bollas (1991) puts it excellently in saying that the Oedipus complex is "known, not thought."
} 
- biographical, paternal dimension. This rupture and closure of a space is one possible way to characterize the prohibition of incest, which "opens" the temporal dimension of subjectivity.

On the contrary, given the fact that the temporal dimension of subjectivity is ridden with "obstacles," what prevails is pathology from before, from the past, and the mother is a space that always reproduces itself in opposition to the future and to survival. This situation, intolerable to modernity, receives from subjectivity the name of compulsion to repeat, while survival is denominated by "limits," "barriers" and "acceptance of desire."

In that case, the Oedipal scenario is not the same as family, but is rather a figure of mediation between the family and social spheres. It assures and consolidates, as apparently the incest situation does, the feeling that the family is in maximally saturated danger (which appears in the imagination as a kind of self-intoxication), so it becomes imperative that one begin another family. Following this logic, there is a social intervention that tries to control familial excess perceived as a danger to modernity. (Ariès \& Duby, 1990b).

Oedipus's end was not in vain - latency, the beginning of school - has to do with the institutionalization of the child. At the mental level, that verifies that there is something beyond the family: the social sphere. The fact that the social sphere appears simultaneously with classmates - fraternity - and with teachers - verticality - obviously has subjective consequences.

The child understands, then, that his or her family is no longer the absolute body that he or she demanded, that there are other bodies and other spaces. Thus, it is no longer sufficient to signal that the passage from what is maternal to femininity is the closure of the spatial - familial sphere in order to continue on to temporality. It must be added that this closure enables passage to a spatial-temporal institution.

In certain ways, the Oedipus complex implicates the parents, but it also involves their disappearance. It is driven by the parents (Laplanche, 1980) yet it guarantees their deactivation as significant figures, in order to implement social values (Aulagnier, 1975). They disappear but resurge in fantasy at the level of exchanges with the future child adult with other adults - probable - promised. This sense of the future enhances their interaction.

To a certain point, the parents are "sacrificed" to the Oedipus scenario, convinced by and identified with social values that require a guarantee of survival and the promise of a future. The opposite scenario, wherein the family exhibits dominance over the Oedipus complex, would imply that the feeling of nostalgia and insecurity prevail over security and basic trust.

The threat of castration is, to Freud (1924) "do not sleep with your mother," to Lacan (1979) "do not reintegrate your product" and to Berenstein (1981), according to the theory of relationship ties, "do not regress to the person who was your giver." The two first sayings are insufficient because they do not realize fully the laws governing modernity, which does not only include prohibition but also regulation and enabling. The law as a form of exchange and regulation is most similar to Lacan's point of view, which states that there be "no reintegration" toward the mother, indicating that there is no way the child could complete her and meanwhile, at some point, the mother no longer desires or values the phallus, which guarantees her child progress toward the genital object.

The child comes to have his own identity, protected in the social sphere, manifested as the law of the symbolic father. The law (social and of modernity), then, shifts away from the family and is replaced by society. The family ends up stripped of power: "the mother loses her identification with the law, with being someone who dictates, the law as an entity that extends beyond character remains in place, so it may be said that the symbolic father is the format of the law" (Bleichmar, 1982, p. 79).

However, if there is at some moment a symbolic father, it is because he is not a simple "representative," but also "delegate" and "counter signer" with clear powers that occupy the respectable position of "adulthood." Psychoanalysis sometimes forgets that an adult is not an immutable, unchangeable figure. The moment the mother and father express that: "there is a law external to us" is the moment coinciding with the understanding that: "we are adults and as such, we know that the law is always external."

It is a structural action that relates positions and places, that implies interaction for the adult, for which there is libidinal and social pleasure in being an adult, which enables one to "renounce" the child as an omnipotent object. The emblems of the paternal figure must be provided and "recognized by the social sphere, so that they are authorized to proclaim themselves integral parts of the social ideal. The parents, both at the beginning and end of the Oedipus complex, maintain - we hope they maintain - intact their plain condition as worthy members of society.

In modernity, the father and mother create a spatial distribution of what is inside and what is outside. The "outside" is the father's work, and the necessary force that work implies, but also danger and the unforeseen. "Inside" is the home, the place of the residence, dreams and protection. The mother remains in the house and it is certainly recognizable that:

The father lives or seems to live by a different order of time, such that we could call it paternal time to distinguish it from maternal time. Maternal time: 1) atemporal 2) instinctual 3) eternal 4) intimate. Paternal time: 1) stormy 2) social 3) mortal 4) impersonal (Bollas, 1993, p. 216).

By definition: it is the division between a space of refuge, protection and care, from a place of obligations and "storms." The father specializes, then, in the temporal, and the mother in the spatial. The mother mitigates inside and outside spaces, 
while the father controls time, coming and going, leaving and returning. Together, they unite for a sense of stability, progress and comfort. Patience in the transition that sends the father away to later return assumes that adults are proud to be adults. The father is supported in his leaving and returning because he is a worker, a quality guaranteed in adulthood.

Nevertheless, both parents are representatives of the social world. The law - traditionally ascribed to the father - does not represent the entire social world, but rather a part of its interrelated web of exchanges. The social sphere, regarding motherhood, is also what Giddens (1991/1997) formulates in terms of "basic trust."

Problematic spatial and temporal discontinuities begin with what is at the subjective level a transitional space, in that it alternates and negotiates between presences and absences. Although the father is absent, he will always return, which expresses a "promise" structure. To clarify, if someone presents him or herself as secure in their adulthood, they stop showing their vulnerability, but not for that reason alone. This is what differentiates a real father from the Father of the Horde (Klein, 2004).

The father in the social sphere seems like another space to the child, apart and mysterious (Bollas, 1993). It is a space that could devour the father and never return him. It is a wonder that I do not ascribe to the theory of the "consummated marriage" between fatherhood and the social sphere. Among them there are "battles" that are not, however, pathological. On the contrary, I believe that they reveal certain "fracture" points in the mediation of these figures that should in theory absolutely always reformulate themselves constantly to guarantee passage from one, threatening, transitory and incomprehensible space to a temporal reorganization that ensures a homeostasis between the social, familial and subjective spheres.

\section{Neoliberalism: The Deprived Family and the Challenges of Parenthood}

Laura Tavares explains that neoliberalism is not limited to: "economic measures of interactive and transitory effects [on the contrary, they bear] social consequences that are serious, permanent, and many times a difficult step backward" (Tavares, 1999, p. 171). This section will develop only one of these consequences: the passage of the nuclear family in Keynesian modernity to what I call a family deprived by neoliberalism. However, it is necessary to mention that transformations within the family form only a part of a wider problem, and one that preceded neoliberalism. The demographic transition away from individualization transformed the relationships involved in production and also included changes in the construction of gender such that women participate more and more in the labor market. Consider the existing quantity of sex changes, new reproductive technologies, and the significant increase in the rate of pregnancy among young and adolescent women; these factors are all relevant (Vasconcelos \& Morgano, 2005).

As I have already begun to develop, it is relevant to bear in mind the role of certain, essential elements of the family in the Keynesian model: home, work, the ability to protect, hospitality and reassurance in the construction of subjectivity. The generous, maternal body and the paternal word of law and order were built into a stable model, an excellent homeostasis, like a "nest" that one can always return to in dreams and memories.

Remember that Araujo (2002) said the "gods" of modernity resided primarily in the work sector, savings, order and physical health and hygiene. It was important to try to be "useful" to society and to "oneself." These elements that maintained balance are now destroyed by neoliberalism:

It has been confirmed, then, that the principal parameters ensuring this fragile harmony have slid (...) Work (...) is more than work, so non-work is more than unemployment, which says a lot (...) This relates to a complete mutation of our relationship with work and as a consequence, our relationship with the world: We would need to invent a totally new way to inhabit this world, or resign ourselves to the Apocalypse (...) The true problem is not just the looming "precarious periphery," but also the "destabilization" of stability (...) In this dynamic, nothing is "marginal." Just as pauperism in the $19^{\text {th }}$ century was carved into the industrial age, precarious employment is a central process, governed by the new technological-economic demands of modern capitalism and its evolution (Castel, 1997, pp. 390-413).

This situation implies a general restructuring of identity and relationships and thus, too, an acute restructuring of the family that reveals the "impact" of social reinsertion. This manifests itself within the family in the disarticulation and confusion of roles, disenchantment with the social sphere, isolation and constant feelings of threat and fear of losing one's job (Araujo, 2002). Humiliation becomes an undeniable fact just like one condition it correlates with: the need to submit (Forrester, 2000). On the central axis of neoliberalism it is what I call: "the feeling of imminent catastrophe" (Klein, 2006).

The family system, then, receives excessive, destabilizing emotions such as shame, depression, and disrespect toward the elderly, as well as upset and blame toward children:

There is a debt, in a sense, paid upward, but it is fundamentally paid downward. This debt incurred by parents is paid by their children. The debt is authoritative, pressing and interminable. It is one debt that cannot be avoided. When external circumstances keep us from paying it off - and we are dishonored for not honoring our obligations - (...) it carries with it an intolerable humiliation (...) For the first time, an entire generation is impeded from paying the debt it incurred (...) The default, a breakdown that prevents the external debt from being paid, not only alludes to the economic disaster that blames us for a commitment made in our name, by whom no 
one knows, but that generates a deep psychical conflict acting as a prohibition so that we may assure our children that they will have the same things our own parents gave us (Volnovich, 2002, pp. 1-2).

This way, we may assume that parents' possibility of maintaining a dignified, honorable image of themselves has been annihilated. Deprived themselves, as adults, it is impossible for them to care for their children, they lose the pride associated with emotionally sustaining a child - which is less important - they suffer the "impact" and perplexity of all of this, and children do not know "how" to be proud of their parent.

This is a disgraceful situation in which the children are now the ones who come to care for their parents. This involves sensitive psychical material, where (Janin, 1989) children become repositories for their parents' worries, placing them in the role of caregiver. They try to keep their parents from falling into states of depression or excess. They do not take care of themselves, which nourishes a politic of selfpunishment and self-sacrifice, so the child starts to function as an object of primary narcissism (Berenstein \& Puget, 1988), losing the regulation of self-esteem, the ability to manage stress and the vitality of desire (Berman et al., 1994).

The construction of subjectivity, then, comes from a place of disorganized attachment (Fonagy, 2000), which does not necessarily relate to physical, but rather psychological abuse. The father-caregiver can never forget "social reality," which allowed the child to grow steadily without worrying about it. On the contrary, the "upset" parents are not protectors, nor are they allowed to continue representing society. In light of that point, instead of being responsible for their own growth, the child becomes responsible for the "downfall" of their parents.

In this way, the child prematurely develops a social structure in his or her mind, which implies some incentive for their role as messiah child which, instead of "nurturing" their own psychic growth, nurtures that of their parents. The child inevitably perceives their parents as abused, transforming the child into an "expert" on the parents' emotional needs and moods (Klein, 2006).

The construction of subjectivity is carried out amid nervous expectation, prevalent insecurity and difficulty forming a cohesive self apart from the parents' identities. Since the parents do not succeed in finding a recognizable version of their selves in the social sphere, the child does not either. Thus, the border of the psychic apparatus responsible for processes of discrimination and differentiation becomes pathological. (Kaës, 1993).

The emphasis on care makes it difficult for the ambivalence that generates mental health to form, because hate is experienced as terrifying and as carrying blame, which is characteristic of the schizo-paranoiac stage of massive projection during identification (Baranger, 1971). The social abuse of parents incapacitates them, making it impossible to sustain the illusion of a self-generated, psychic apparatus in their children. The parents worry about the family, using (whenever possible) desperate survival practices.

It is important to clarify that, although the social sphere is always present, it is not always the same as what is "revealed" through family mediation, during which it is imposed as a force that invades and empties the family system. Instead of being a silent area, it becomes a "scream" that brings on a break down of the intersubjective capacity of the psychic apparatus, imposing violent and transsubjective phenomena (Kaës, 1993). I often ask myself if this situation is comparable to the phenomenon known as psychophobia (Valdré, 1998) that is found in adolescents, and quite serious, wherein the very activity of thinking is feared and avoided.

Based on Winnicott's work (1981), we can acknowledge the importance of being able to depend on adequate means of sustenance and of maintaining a predictable and sufficiently good environment that establishes feelings of control and recognition. Thus, within the modern, Keynesian matrix, parents might fear the exogamous "outcome" for their child, but not in greater measure than the family's pride and hope for a descendent who will obtain autonomy and decision-making capacity. The downside, on the other hand, is living with the loom of imminent catastrophe, which definitely implies a passage from one's roles as a parent, caregiver and protector, to a vulnerable parental status.

In that way, the processes of dialog and affective exchange, symbolic and interactive, (Lyons-Ruth, 2004) are substituted for ambiguous messages, double messages or unspeakable secrets that cannot be confessed. This accentuates the processes of endogamy and the closing-in of the, not so much due to a lack of paternal functioning as to an increasing defense system of family protection in the face of generalized vulnerability.

What I refer to as the politic of trial and error, the adolescent's important ability to explore new and spontaneous (Klein, 2003) experiences, is in danger of extinction. It is being substituted by a politic of disaccord, which is related to an unexpected and incomprehensible situation that "tears away at" the stable foundation of the middle class, and society in general.

If the father of the clan can confirm that (Freud, 1913): I am the law because I have the power, I am indisputable," then the opposite father figure may be construed as weak and in a state of ruin. He would not be a strong father, he would not be believed to be strong, nor would he be seen as strong. Roudinesco indicates how the father, "due to his economic impotence, no longer brings fear" (Roudinesco, 2003, p. 154). If sometimes, in the world of clowns and circus life, an ogrefather appears, this is because in the world of reality, the father figure is lost in a state of confusion.

He can be neither the terrible father from the second stage of the Oedipus complex (Lacan, 1979), nor the father who represents the law - the paternal function - in the name 
of society, which in reality he devalues. According to Joel Birman's (2001) analysis, the paternal function is articulated decisively in the social sphere:

And on this specific point, I would like to focus my criticism of Lacan's literature about the law: that it could escape certain consequences that are inevitable in an interpretation of justice (...) In Brazil, the law is truly a dead language, completely dissociated from the social practices of justice. The symbolic conceptualization of the law cannot restrict it simply to linguistic processes; it should definitely be re-launched in social and political camps in which the political economy, where goods and values are exchanged in the social sphere, attacks the psychic economy of the impulses, desires and demands of social agents (...) I believe that the functioning of Brazilian society allows us to concretely perceive, and from a privileged standpoint, the interval between the symbolic register of the law and the normative functioning of justice (Birman, 2001, pp. 280-281).

I, any case, should clarify that this change in the paternal function is inseparable from the dissolving structure of the nuclear family, tied to a long process that extends far beyond neoliberalism. In this sense, a progressive "socialization" of several aspects of family is apparent, and social institutions (school, religion, etc.) assume parts of the maternal and paternal roles. Therefore, social structures create a change in the family that must be considered in depth:

The family resembles an unusual tribe, an asexual, fraternal web without hierarchy or authority in which each person feels autonomous or as though they serve a function (...) Thus, paternal domination can only exercise itself in cases of consented co-participation that respects the position of each member connected by the institution of marriage (...) Injured in both body and spirit, the mutilated patriarch of the new, symbolic order can no longer claim to be of value as more than the don of his family name to claim his right to a sort of "adopted" nomination (...) In the following, the father shares power over the child with the mother, and his old prerogatives, debilitated by the decades, are reduced to practically nothing. The family is converted, then, into "coparental" form and we begin to hear about "coparenting” (Roudinesco, 2003, pp. 168-111).

The shifting roles Roudinesco describes may be better described in light of certain changes that are produced more and more pronouncedly. Along those lines, it might be better to indicate that it is not that "there is no longer a need for a father" but rather that aspects of the paternal role have become impossible or have been extinguished:

Unemployment as a mark of identity instead of as a temporary state, as well as feelings of shame, tell us about new, erroneous conditions of authority (...) they deprive fathers of value and, consequently, of authority. Contemporary men and women are no longer able to recognize a command, neither to reject it nor to obey it (Duschatzky \& Corea, 2002, pp. 61-79).
Because of this, the family unit has endured substantial changes:

The child's subjectivity (...) has no point of reference in adult figures in the family or at school; on the contrary, adult figures are referred to with aggression, injury and sometimes in expressions oscillating between complaint and the protest that no one listens to them (...) The father figure is practically absent and the mother is insinuated as impotent and suffering (...) The family is no longer a place to transmit the law through a paternal figure; work is no longer an area that reinforces the role of the father as the provider for the family; and the mandate on education, rooted in the belief that to study guaranteed a better future, has been destroyed (Duschatzky \&Corea, 2002, p. 63).

The fact that the weak father is insufficient for the operation of a symbolic system (Dofour, 2005) is imposed by Keynes's style of modernity, which implies an abandonment of the subject to luck and a relocation of temporal linearity, "and with it, a rupture of inter-generational ties, in other words, a rupture between the past and the present" (Hobsbawm, 1995, p. 25).

When a father no longer knows what it means to be a father, there is a break-down in temporality, and discontinuity comes to dominate over continuity. Equivalently, when the mother no longer occupies her role as intermediary between the inside space of the home and the outside, social space, it is difficult to establish a transitional space. This coincides with a predominant feeling of emptiness.

For adolescents especially, this makes access to generational confrontation impossible (Winnicott, 1972), which requires adults that are recognizable as such, who sustain their power and decision-making agency. This situation shows that a social base no longer exists from which an adult may neither project him or herself, nor sustain and propagate him or herself as a parent. The structures that mediate the transformation of mental representations in the psychic system of the child are lost (Klein, 2003, 2006).

In their place are ties of negligence and doubt (Kancyper, 1997). Structural conditions that are crucial to the construction of subjectivity are being lost:

The real presence of a father-or another individual able

to create real presence - is paramount for the "operation of a symbolic system" that fosters ethics and subjectivity, which are necessary for the subject's social life (Gryner, 2003, p. 136).

Thus, the modern family is considered to "emerge from the beginnings of a social change" (Wainerman, 1996 , p. 212) wherein family is no longer, and cannot be, an intermediary figure between its members and society: "family is not only defined as an essential societal force (...) it is apparently necessary for any sort of subjective rebellion: children against parents, citizens against the State, individuals against the masses" (Roudinesco, 2003, p. 97). 
The way an adolescent confronts his or her family dilutes and directs their aggression, which allows for growth (Winnicott, 1972), but acts as an antagonist ${ }^{4}$ toward the family, with subjectivity that is, as it unfolds, complicated by rebellion and confrontation (Klein, 2002, 2003, 2004). The fact that this dimension cannot sustain itself anymore gives an incentive to heteroclite ${ }^{5}$ subjectivity for which uncontrolled, irregular, ominous life events prevail in subjectivity, a result of the "shattering" of a doubly protective environment: the sustained family and the psychic border's guarantee that one "takes care of him or herself" (Klein, 2006) .

\section{A Father In Search of Fatherhood}

This study seeks to find out how certain social situations cannot help but interfere in subjectivity and family ties. Keynesian modernity proposed a socioeconomic matrix that was relatively stable, with the premise of probable survival and the declaration of an achievable promise. It tried to frame it within a predictable economic context with social stability. Furthermore, it suggested a sort of social homeostasis belonging to the rule of constancy (Laplanche $\&$ Pontalis, 1981) that posits psychic functioning as both a social regulator and a familial organizer.

On the other hand, neoliberalism - as a social, economic and political model - generates a "disintegration" of life's spaces, social identity and the joy of social participation. When there is simultaneously a "rupture" of the social fabric and the principle of constancy is broken, plausible systems of explanation turn out to be partial and insufficient. Therefore, it is critical that we reconsider the theories surrounding, as well as the devices used to construct subjectivity and new relationships.

One of these factors has to do with fatherhood. Keep in mind that the father provides the signs of certainty needed to carry out life projects and trophic growth processes. However, the father that young people transmit (Klein, 2006) seems to increasingly resemble an untouchable entity that cannot be found: an enigma. It is no longer a fixed value, a kind of certainty. On the contrary, the message transmitted is that we no longer know who the father is, what a father is or what makes a father.

He remains in a distant place, perhaps expelled by his own children, or maybe he sent himself away. This weak, absent, unrecognizable father is not able to receive hate from his children (and I mean hate in the Winnicottian sense (Winnicott, 1972) of aggression in the service of growth), nor can he receive their love. In this case, there is something ambivalent that goes unarticulated and fragmented, which explains why extreme attitudes of resentment and/or guilt are emphasized.

As terribly as this matter could end up, the Freudian Father of the Clan (Freud, 1913) is here, he is present and he directs, orders and guides. On the other hand, this version of the father does not give orders, nor does he have a voice. $\mathrm{He}$ is a father that exists only in the pages of a phonebook. He knows nothing about the law. Instead of aligning himself with his children, he disowns or is indifferent toward them.

Nevertheless, I do believe that there is a symbolic dimension of the father that cannot be denied. Much of it is found, as I already mentioned, in the several institutions that comprise the socialization of fatherhood. However, I find that for many adolescents (Klein, 2006), seeking fatherhood turns into a compulsion that establishes a search as dramatic as it is fruitless, and that reveals how, in this dilemma, something integral to growth is put at stake. The compulsivity, contrary to what would be expected, is not at the service of sickness, but rather that of health.

In a sense, the neoliberal context establishes a disassociation between the familial and the parental. The expected movement toward identity consolidation and social reassurance belonging to the nuclear family seem to have undergone radical changes in order to maintain the endogamy factor - exogamy, the simple passage of the original family to the future family, stops making sense (Klein, 2006).

It interests me to locate kids' so-called "familiar novel" in this way. According to Freud (Laplanche \& Pontalis, 1981), it is understood as a fantasy by which current parents are substituted by others, which indulges in marvelous, narcissistic attributes. On the contrary, the aforementioned familiar novel does not seek to modify those attributes, but to make them adopt certain points left out of the Freudian version whose absence leads to suffering. It is no longer a matter of whether the father is adoptive or not. On the contrary, they un-adopt their kids, instead having nothing to do with them, which begs a question of alignment where it ought not to be.

I believe, then, that the question of alignment, of succession and inheritance - not present in the Freudian, familiar novel - is perhaps resolved through a fraternal novel. I cannot go into depth on this theme but perhaps these kids feel in a way more "adopted," cared for and cleaned up after by their siblings more than by their biological parents. In any case, this marks a fundamental difference in the configuration of the family system.

\footnotetext{
4 Antagonism is when an individual executes movements contrary to what was indicated to them (VISOR, 1999).

5 Heteroclite is when certain phenomena contradict grammatical rules (VISOR, 1999).Heteroclite is when certain phenomena contradict grammatical rules (VISOR, 1999).
} 
I will elaborate upon what has already been said: to continue to maintain the Oedipus complex as a structural reference, in its conventional conception, is oversimplifying because of the need to include the fraternal complex (Kancyper, 1997) as a fundamental dimension of subjectivity. In that sense, the incest-castration pair, which continues to be a valid descriptor, should be complimented by aligned versus unaligned pairs.

The fraternal novel is inseparable from fatherhood and its doubles. The father is no longer guaranteed fatherhood, which has come to include other figures: uncle, grandfather, stepfather, brother and professor, with guaranteed structural recognition in all cases.

Nevertheless, it is important to emphasize that, meanwhile, fraternity also implicates a system of rivalry and violence between two opposing groups: excluded and included, preferred and relegated, sign and insignificant (Lewkowicz, 2004).

\section{The Structure of Upset Parents}

It is worth considering, then, whether the father-mother pair (in the regressive-prospective sense) has not been substituted by others, like the brother-grandmother pair, in a search for dialog they are incapable of sustaining, It is imbued as if in a "suffocating" environment where neoliberalism's divestment creates what I call the structure of upset parents (Klein, 2006).

These parents are too busy managing social survival to simultaneously maintain family communication and dialog, so it becomes impossible to sustain a libidinal space for the children, and they are chronically excluded from an encounter that would have otherwise strengthened them.

I understand that an error that is repeatedly made is that parents do not carry out a generational confrontation with their children, since the parents disguise themselves as "adolescents." This point of view has its faults, in my opinion. Adults do not want to be adolescents; they want to be young, which is not the same thing at all. If they avoid confrontation with their children, it is because they feel incapable of managing that situation because elements of emotional upset (structure of upset parents) nullify essential qualities like strength and security.

Having rejected the confrontation possibility (Winnicott, 1972), an adolescent's world is solidified and sealed, guards secrets and feared scenes, and fuses relationship ties. The remaining option, then, is not to separate, to assemble a single family skin, taking mutual care of each other, building a scene where change "freezes," to exacerbate the threading scene (Klein, 2006). That is capable of nullifying all growth, which is inevitably experienced as incomprehensible and horrific. Nothing will ever be the same, subjectively and in terms of relationships, from then onward.
Developments and Manifestations in the Everyday Lives of Adolescents

Next, I will introduce the impact that these cultural, family and social changes may entail in the world of adolescence. I do not intend to exhaust the theme, but to at least stress some aspects that seem relevant to me as important systems that organize the world of adolescence (Klein, 2006).

One such aspect has to do with how new family systems emerge from shifting models of parenthood, and how parenthood cannot help but impact the place that young people occupy as children ("exacerbated messiah complex" phenomenon). On a related topic, I will outline a dimension that I consider essential to understanding contemporary adolescent subculture (the fraternal order).

The clinical stories that follow come from a therapy group I coordinated 19 years ago in the Area of Adolescence, Psychotherapy Program of Clinical Psychiatry in the School of Medicine. As I already mentioned in I), they are simply presented as a rich way of developing my hypotheses. In no way do they attempt - within the limits of this essay to serve as empirical evidence.

On the exacerbated messiah complex or spending all one's time "care taking."

D. I...(...)...have to be serious, doing your work, you can't get out of it because you have siblings, you have to take care of them and you can't do what you really want to do.

L. I don't think it is because one is better and the other worse. Parents always have an image of how their children should be, they have demands (...).

A. - Other people make decisions for me. I have always been very attached to my family, they always say yes and when they say no, I feel lonely, like they have pushed me aside...My boyfriend always tells me I do not need them to take care of me, I need them to help me.

P. - You are responsible, you do things well, and they are going to go well...

D. - Other people want to put the responsibility on you because you are older.

L. - To older siblings, greater responsibility, to younger siblings, less responsibility...

P. - If they leave, I have to take care of the house and my neighborhood is really bad. At night, there is a gang...That is why I am big.

L. - That might be, but in my case, I don't have to take care of the house and it's the same.

D. - I have two younger brothers and I work next door to the house. My neighborhood is also tough and I have to leave every 15 minutes to see if everything is okay.

P. - If my parents and my sister leave, I stay outside with one or two friends and turn my music all the way up, but I don't feel afraid. 
D. - A professor said that we do not take care of the chairs because they are public, but that it they were privatized, we would take care of them, and I agreed but could not tell my friends. ${ }^{6}$

The above fragments demonstrate what I would call subjectivity or adolescence "on tip-toes." That means among other things - less familial tolerance of mood problems, conflicts, rebellion, or opposition behaviors: "I have to be serious, to do my work, you can't get out of it because you have siblings, you have to take care of them and you can't do what you really want to do."

The needs of a baby are given the incentive, seeking to be protected and contained, as long as that reality remains clandestine. Instead of there being an existential continuity, there is more of an existential split. It is one thing to be with one's friends and another to be with one's parents. With them, certain behavior is "expected" from an adolescent, while around the family, close relationship ties unfold.

The regressive need to be contained makes the adolescent appear dangerous in the face of the "loss" of that contact which, for them, is crucial. Their extreme need to be cared for makes it such that, paradoxically, the ones who show themselves to be lacking are cared for most.

One aspect of this type of subjectivity is what they transmit with their upset feelings: They can no longer stop taking care. This situation speaks to the poor state of the communication of obligations, while the right to do other activities is not recognized. In this way, the possibility of learning to take care of oneself is restricted.

Together with permanent care, an anxious flurry of active interpretation is implemented, which detects signs of rejection and/or belonging, seeking to understand the codes by which they may be incorporated into family and/or social relationships ("You are responsible, you do things well and they are going to go well...") On the other hand, however, in these groups, the conditions of belonging are rigid ("Parents always have an image of how their children should be, they have demands (...)."

One behavior that expresses the above is what is referred to as the exacerbated messiah complex. As I already mentioned in earlier studies (Klein, 2003), the messiah complex (a concept driven by Kancyper, 1992, 1997) is a structural activity of adolescence:

In some way, its presence ensures a persistent investment on the part of the family, beyond the changes of this period (...) It could be said, then, that if "the baby's majesty" is an inescapable structural condition, "its messiah, the adolescent," should be no less (Klein, 2003, p. 124).

In this way, we hope that the adolescent is at once propped up and neglected through the family, the Oedipus complex, confrontation, the group of pairs, the messiah complex, the future, education and other factors. This situation has a healthy potential given that when one eventually needs to use crisis and change structures, they will be in place and flexible, because the psyche will already have developed the support of multiple factors. The more multifaceted the subjectivity is (Bernard, 2001), the more complicated the individual's psyche becomes.

On the other hand, the material presented suggests that adolescence, rather than being a threading scene, as an opportunity for change, comes to be a feared encounter, making the structures that mediate between the adolescent and their adolescence more fragile. Thus, there tends to be only a single support for a frozen scene that allows them to avoid mounting troubles and reproaches for being adolescents.

Losing adolescence is "an intense process of translation that must be seen as losing supports and later gaining them back" (Klein, 2003, p. 171). A single-support system is formed because the problem is that young people do not know HOW to move between different structures (infancyadolescence; adolescence-adulthood).

The material studied gives the impression that the messiah complex is the only [or predominant] support that an adolescent possesses to sustain his or her family ties. It is for that reason that I call it "exacerbated." Leaving the messiah complex behind is experienced as a catastrophic situation that provokes feelings of anxiety in adolescents.

"Messiah" responsibilities seem to take on a wider and more centrifuged area every time: taking care of the house, siblings, chairs, home and family harmony, until the point when it gives the impression that it is not the adolescent who "depends" on the world, but the world that depends on the adolescent. Fraternal bonds become fraternal "burdens" ("...Other people want to put the responsibility on you because you are older... To older siblings goes greater responsibility, to younger siblings, less responsibility...").

The spirit that is conjured to assume this role (or better said: the word), would most likely be loss; loss of family, loss of peace, loss of balance or homeostasis for the species, and so adolescents become guardians. Giving up one's place as messiah could entail imminent dangers: robberies ("they robbed one of the houses next door to mine"), destruction ("At night, there is a gang..."), accidents ("I have to take care of my sister because she goes out to the street") absences ("She goes with her friends and forgets to be careful") and divorces ("I never accepted that my parents would separate. There were problems between them...").

This situation is inseparable from what I call an imminent catastrophe situation (Klein, 2006). At the same time, it is tied to another: the unquestionable obligation situation. In

6 D. and P. are boys, L. and A. are girls. 
the latter, if a situation transmits discomfort ("Right, but at night, it's: don't drink, don't smoke, for that they always highlight the rules") and double meaning ("If they leave, I have to take care of the house and my neighborhood is really bad. At night, there is a gang...That is why I am big"), they can do nothing but act "obedient," which perhaps reflects the persistent transmission of a dictatorial grammar from the more or less recent past in so many countries in Latin America.

This may involve compulsive behavior, maybe in the style of obsessive ritual ("I have two younger brothers and I work next door to the house. My neighborhood is also tough and I have to leave every 15 minutes to see if everything is okay") or maybe in an attempt to avoid the experience of terrible loneliness: "Yes, I have to be alone. I shut myself up in my room, put the music on loud; if my parents and my sister leave, I stay outside with one or two friends and turn the music all the way up, but I don't feel afraid." Trying to avoid the experience of terrible loneliness:

In this way, possible psychic problems are substituted by an adaptive force. In a sense, they try to nullify conflict situations by resolving them with force and will power. At the same time, the situations worsen to become questions of life or death.

Disobedience comes to be related to experiences of vulnerability, so adolescents do not feel that they have the power to change their behavior, and seem resigned and devitalized. The feeling of "being at someone's mercy" implies that subjectivity is regulated largely externally, at the family or institutional level.

The exacerbated messiah complex is, itself, related to the impossibility of expressing pain for the family that no longer exists, to which experiences of protection and care are associated. This sort of prolonged, "happy infancy" seeks to deny, more than the end of infancy, the changes in one's parents have undergone since infancy. In their place, what I have called "upset parents" emerge, who transmit feelings of vulnerability.

Even though protective parents become vulnerable parents, it is a reality that they can neither accept nor tolerate, feeling that if that illusion (that they protect and bring harmony and security) breaks, frightening effects may come as a result. What relieves and calms them down is for everything to remain static and unchanging.

I suggest as a hypothesis-in-progress that the problem at hand relating to the family is double: on the one hand, adolescents ask themselves how to get rid of these parents without feeling guilty. On the other hand, they create a situation of fusion with the parents, trying to deny the shame that they provoke in them.

This situation does not facilitate growth nor does it change any structures; instead (maybe as a form of compromise between change and non-change) another side appears, the exacerbated messiah complex: an accentuated, overly demanding psychic relationship with the family group.
In the classic model of Keynesian modernity, family was the essence of growth. It involved sustaining and collaborating with the social sphere, a model which ended up generating viable, vital conditions of "detachment." In the passage from endogamy to exogamy, when things are "sufficiently well-provided for," they are not internalized as doubt because doubt does not get transmitted (Volnovich, 2002), it generates survival.

On the other hand, young people transmit difficulty growing. Instead of facilitating conditions for progress, what their parents transmit are enigmatic messages (Laplanche, 1987) such as: "something horrible may happen;" "save us;" "always think of us" and others.

When young people receive enigmatic messages, they seem to reinterpret them according to a single code: "the exacerbated messiah complex." Using this code, the only meaning they interpret from enigmatic codes is that they need to protect their parents, the house, their siblings, the neighborhood and their school. Above all, the message is to take care, even when fatigued and confused.

They do not know with absolute certainty who their father is, how to communicate with their mother, or what ties unite them to the social sphere, but they do know that it is imperative to remain alert and to protect. They have no doubt that, whoever their father is, he is weak and fragile. I already mentioned that with a weak father, it is very difficult to experience confrontation, as Winnicott (1972) describes. In that sense, I believe that the exacerbated messiah complex is an anti-confrontational structure that prevents one from placing aggression at the service of growth.

Notes on fraternity or constant comparison as an element of adolescent culture. P.'s comments at the beginning of a session:

I feel like a 19-year-old boy because they order me around, yet I do what I want. After the age of fifteen is another stage, except that when I come home (from going out) they always ask me: "What did you do? Where did you go?" It's always the same. "Who were you with?" Adults don't think that they were ever kids themselves, that they did the same things, or different ones.

Coming and going imply rituals through which prohibitions and permission are constructed. The ritual of leaving has to do with having to do homework, while coming home involves an interrogation to know where and with who they were. The everyday world is shaped as a world of obligations where the kid experiences strong interrogation and demands:

\footnotetext{
$P$. - You have to study if you are not going to become a vagabond.

L. - In my case, it is a responsibility that's internalized as if by a machine, a machine they program. When you are 15, it isn't that they don't trust you, but that they have to tell you; now they don't need to tell you.
} 
However, are the rules of the game in the adult world clearly delineated? I think not, and that a great part of the force that adults exercise goes toward trying to understand what they are. In this "anti-moratorium" where obligations are given incentives, yet it is not always clear what, and how extensive, they are. What is interesting is that being eighteen no longer implies legal adulthood: in some matters it may mean the adolescent is still small and in others too big. It is worth mentioning that infancy and adolescence coexist; big and small coexist:

(P.: "There are some matters where I am still little, but in others, no, I am big," D.: "Other people want to put the responsibility on you because you are older").

However, this ambiguity is part of a world where the possibility of change is nullified. For that reason, it becomes necessary to rethink what exactly adolescence is in the context of an intolerant and institution-based society. Things are programmed, calculated, lied about, and hidden, and with no apparent margin for improvisation, newness or originality. The place of the adolescent, as I have already mentioned, is to participate in clear and precise activities: take care of siblings, study, spend time with parents (P.- "If they leave, I have to take care of the house and my neighborhood is really bad; at night there is a gang").

The politics of trial and error that I referred to in my earlier work as an axis of adolescence is not established (Klein, 2003). Perhaps the scene feared (or maybe it is deeply desired) by young people is to become "vagabonds," or said another way, to break away from the hyper-adaptation of care-giving prescribed by the exacerbated messiah complex. It is definitely true that adolescents undergo a permanent test to prove they are not vagabonds, so that they may be worthy of their parents' love.

In this scenario, completing one's obligations guarantees that the parents are permanently dependent upon them: P: “...I have two friends that can't stand to be at home and if their parents ever leave, they are going to have huge parties at their houses."

Thus, one must demonstrate that they are "big," although growing up seems to be viewed as a price to be paid, part of a permanent demand to adapt: P. - "Sunday, I demonstrated that I'm not a boy, now they trust me; there was something that needed to be done at work and my father put me in charge: "At this time, take the car and go to this place," and I did it all."

I would like to remark upon the following point: For young people, to be a kid means to be a person that cannot be trusted. To be big, on the other hand, means that a person can be trusted. This idea seems to be reinforced by parents, too. Does an adolescent live under constant "interrogation?" One has to prove that they can be trusted, so there is a need to do things "well," which diminishes the possibility of fighting or argument; conflict becomes very fragile.

From there, a type of adolescence is forged that requires a calm climate and reconciliation with the parents with no unpleasantness, conflicts, insults, or confrontations that were to be expected in the "typical" case of adolescents inhabiting the Keynesian, modern world.

At the same time, they transmit feelings of loss, denigration, deficit, that something is missing, and this may be related to the fear of not being able to meet the standards of this demanding world. I ask myself, then, if fear is not centered on not being able to handle imposed responsibility. The question becomes to what extent young people can reconcile their adolescence with a heavy load of responsibilities.

Consider this aggravator: the situation is such that when they do not accomplish proposed tasks, they are denigrated and compared to their parents or to other siblings that can do it, so the experience of being an adolescent is a humiliating one.

The prevailing strategy seems to be to live adolescence "as if" one were actually an adolescent, in other words, by going to dances, drinking a lot of beer and spending the weekends more or less intoxicated. It is a state of pseudoadolescence, which I define as adherence to adolescence (Klein, 2006) because it does not transmit that which is most stirring and significant about adolescence, like psychic and identity permutations.

On the contrary, what prevails is more of a predictable caricature of an imaginary social sphere: drinking, sex, and living on the edge, compulsively. Adolescence is a way of life, but as I have had the opportunity to develop, it is no longer a demand of psychic activity (Klein, 2004).

I wonder if parents of these adolescents experience (and treat) their children using a constant double register: they go from being marvelous heroes (of the exacerbated messiah complex) to being deceptive (being compared-the fraternal system). It is about - as I have already developed - the existence of an insufficient scopic dimension that causes oscillations between pride and worry, unable to build character that can be sustained and protected.

As could be expected, I take the fraternal system to be a structure of comparison, comparison of the ideal of adolescence and adolescence as it actually is. However, I also believe the relationship between siblings is essential. R. tells us that he covered his eyes to his sister's birth, feeling like he had ceased to exist to his mother.

What is especially interesting to me to clarify is that this is the source of the argument that if one person is chosen, it is because some other person is excluded, rejected, or expelled. It is important to say: The family and/or social sphere is a closed, small space where not everyone has a place. Certain people have a place in it and others will never have one. That is what most characterizes the shift from the feeling of growing up in an expansive society (characteristic of Keynesian modernity) to the feeling of being expelled from a smaller society.

Still, it must be said that fraternity is not only related to the exclusivity and tanatic associated with resentment and 
the exclusion of social relationships. It also presents a relevant dimension for the union and health associated with support and solidarity (Czernikowski, 2003). Na. says:

I have a brother, my sister is 13, my brother is 21 and I am in the middle. Like everyone who has siblings, we have preferences. For me, ... (cries) I prefer my older brother. To me, he has always been, and continues to be, the best.

From this perspective, it is revealed that rejection by one's sibling is intolerable. Faced with parental vulnerability, a fraternal preference is formed as an absolute certainty in which feelings of care and protection are settled that allow for the restoration of trust and a certain kind of social tie. On the other hand, the sibling figure falls below the articulation of the ideal self as a way to mentally organize that becomes increasingly dense around unquestionable, maximally-idealized characteristics (Bleichmar, 1981). It is an idealized object also idealized within a dimension that compensates the insufficiency of the scopic provisions of the parents.

On the other hand, tanatic fraternity involves strong feelings of resentment and rancor that reflect disjunction and the act of coping with being displaced by someone else who dominates, which entails tremendous stress:

D. - I have a grudge about something. He left us [my father] when I was three and he had never, never given me a gift. As a boy, I didn't celebrate my birthday; I didn't like it.

L. - I have an adopted cousin and they compare me to her constantly, saying that she is grown up, she's already 12, and that she is pretty...

In this dimension of fraternity, there is a two-way, intolerable incentive to being constantly compared to others. It is insisted upon that an adolescent compare their parents with other parents (their friends', their boy or girlfriend's, etc.) (Freire de Garbarino, 1988), but nothing has been said of the fact that at the same time, adolescents are repeatedly compared to other adolescents. It may be that relief comes from the introduction of another type of relationship (with grandparents, for example) where adolescents are accepted as they are. Na.: "I was talking to my aunt and my grandmother. I communicate well with my grandmother."

\section{Conclusions: Adolescents without Adolescence}

It is commonplace to hear people comment that adolescents today are disenchanted, that they do not worry about anything. Classic, psychoanalytic authors (Hanna Freud, 1985) repeatedly posit that: the adolescent always seems to be looking outward, toward some other thing, "navigating" their personal and intangible world.

My point of view is diametrically opposed: they are not looking "outside;" rather, they cannot help but look, think and worry about the "interior." In other words, they cannot stop being attentive to their families, procuring care, protection or comfort.
In this way, the adolescent world appears to be something that is constantly falling or being destabilized. What was once solid and safe has now passed, only to be subjected to vulnerability and mistreatment. However, there are points of "resistance" (D. - "I resist having more responsibilities than I should have") that allow for possible argument or opposition.

It seems that what these adolescents consider adolescence is a complex juxtaposition of spaces of growth and stagnancy; spaces of being big and spaces of being small; spaces of very intense rivalry and spaces of constant negotiation in their internal world.

For that reason, there is no longer - like in modernity - "markers" that clearly identify a "before" and an "after" (Dolto, 1990) of adolescence. On the contrary, a dense geography of the psyche and relationships rules that is deceiving, ambiguous and at times, insoluble. Along those lines, to be an adolescent implies a constant debate about what they can and cannot do.

I believe that the dependence-independence dyad cannot be used as a simple descriptor of these adolescents' experiences. Responsibility is no longer an index of autonomy; it has come to be grounds for denigrating comparison. It is fragility in a fluid state (Lewkowicz, 2004).

Contrary to Keynesian modernity, this adolescence is not founded on, nor does it tolerate conflict or generational confrontation. Therefore, a "tenuous," "fragile" adolescence is formed, implying a model of subjectivity called adolescents without adolescence (Klein, 2006). Other social and subjective factors enter into this model that would be impossible to elaborate upon here.

Are there examples of fragile adolescence?: non-future, ominous parents, existential worries, violence. There are histories and experiences annulled that are never woven into biography and vulnerabilities become chronic and collapse into a repetitive spiral. The order of the precarious stands in the place of adolescent joy (Urribarri, 1990).

I believe this precariousness comes in three parts: social, family and at the subjective level. On the social level, it implies an extreme fragility of working and studying conditions (transformed neoliberally into the labor and education markets) that go from representing conditions of security and continuity to being defined by a threat. The threat implies a constant sense of uncertainty where unbreakable situations begin to break.

Precariousness on the family level implies the crumbling of differentiated places and complementary roles in favor of unifying structures where fatherhood is inexplicable and motherhood is distrusted, breaking a pact of essential trust, to which new elements can add and articulate themselves. The family space begins to incorporate secrets, confusing situations and exclusionist attitudes.

Finally, at the subjective level, precariousness implies (among other factors) that growth is experienced as extreme responsibility, like an irritating task imposed as a kind of curse. 


\section{References}

Araujo, A. (Org.). (2002). Impactos del desempleo. Transformaciones en la subjetividad. Montevideo: Alternativas. Ariès, PH., \& Duby, G. (Orgs.). (1990). Historia de la vida privada, Vol. II: La alta Edad Media. Buenos Aires: Taurus.

Ariès, PH., \& Duby, G. (Orgs.). (1990). Historia de la vida privada, Vol. VII: La revolución francesa y el asentamiento de la sociedad burguesa. Buenos Aires: Taurus.

Aulagnier, P. (1975). La violencia de la interpretación. Del pictograma al enunciado. Buenos Aires Amorrortu.

Baranger, W. (1971) Posición y objeto en la obra de Melanie Klein. Buenos Aires: Kargieman.

Berenstein, I. (1981). Psicoanálisis de la Estructura Familiar-Del destino a la significación. Argentina: Paidós.

Berenstein, I., \& Puget, J. (1988). Psicoanálisis de la pareja matrimonial. Buenos Aires: Paidós.

Berman, S., Edelman, L., Kordon, D., Müller-Hohagen, J., Pavlovsky, E., Stoffels, H., \& Viñar, M. (1994). Efectos psicosociales de la represión política. Sus secuelas en Alemania, Argentina y Uruguay. Buenos Aires: Goethe Institut.

Bernard, M. (1991). Introducción a la lectura de la obra de René Kaës. Buenos Aires: Asociación Argentina de Psicología y Psicoterapia de Grupos.

Bernard, M. (2001). Los vínculos en el psicoanálisis francés contemporáneo-Una aproximación crítica a la obra de René Kaës. Buenos Aires: Asociación Argentina de Psicología y Psicoterapia de Grupos.

Birman, J. (2001). Mal-estar na atualidade. Río de Janeiro: Civilizaçao Brasileira.

Bleichmar, H. (1981). El narcisismo - Estudio sobre la enunciación y la gramática inconsciente. Buenos Aires: Nueva Visión.

Bleichmar, H. (1982). Introducción al estudio de las perversiones. Buenos Aires: Nueva Visión.

Bollas, C. (1991). La sombra del objeto - Psicoanálisis de lo sabido no pensado. Buenos Aires: Amorrortu.

Bollas, C. (1993). Fuerzas de destino. Psicoanálisis e idioma humano. Buenos Aires: Amorrortu.

Brandt, L. \& Giovacchini, P. \& Lobel, L., et al. (1989). Adolescentes borderline. Buenos Aires: Nueva Visión.

Castel, R. (1997). Las metamorfosis de la cuestión social. Una crónica del salariado. Buenos Aires: Paidós.

Dolto, F. (1990). La causa de los adolescentes. Barcelona: Seix Barral.

Duschatzky, S., \& Corea, C. (2002). Chicos en banda. Los caminos de la subjetividad en el declive de las instituciones. Buenos Aires: Paidós.

Fonagy, P. (1999). Persistencias transgeneracionales del apego: una nueva teoría. Revista Aperturas Psicoanalíticas, 3, http://www.aperturas.org/3fonagy.html.

Fonagy, P. (1999). Apegos patológicos y acción terapéutica. Revista Aperturas Psicoanalíticas, 4: http://www.aperturas.org/4fonagy.html.

Forrester, V. (2000). Una extraña dictadura. Buenos Aires: Fondo de Cultura Económica.
Freire de Garbarino, M., \& Frioni de Ortega, M. (1988). Interpretación y psicoanálisis durante la adolescencia. Revista Uruguaya de Psicoanálisis, 68, 69-74.

Freud, S. (1913). Tótem y tabú. Vol. XIII. Buenos Aires: Amorrortu. Freud, S. (1924) El desactivamiento del complejo de Edipo. Vol. XIX. Buenos Aires: Amorrortu.

Giddens, A. (1991). Modernity and self-identity: Self and society in the late modern age. Cambridge, UK: Polity Press, 1991 [Spanish translation: Modernidad e identidad del yo. Barcelona: Península, 1997].

Green, A. (1994). De locuras privadas. Buenos Aires: Amorrortu.

Janin, B. (1989). Aportes para repensar la psicopatología de la infancia y la adolescencia. Revista Argentina de Psicología, 40.

Kaës, R. (1993). El grupo y el sujeto del grupo. Elementos para una teoría psicoanalítica del grupo. Buenos Aires: Amorrortu.

Kaës, R. (1994). La dimensión psicoanalítica de grupo. Buenos Aires: Asociación Argentina de Psicología y Psicoterapia de grupo.

Kancyper, L. (1992). Resentimiento y remordimiento - Estudio psicoanalítico. Buenos Aires: Paidós.

Kancyper, L. (1997). La confrontación generacional. Buenos Aires: Paidós.

Klein, A. (2002). Imágenes del adolescente desde el psicoanálisis y el imaginario social. Condiciones de surgimiento de la adolescencia desde la modernidad y el disciplinamiento adolescentizante desde la pos-modernidad. Montevideo: Psicolibros.

Klein, A. (2003). Escritos psicoanalíticos sobre psicoterapia, adolescencia y grupo. Montevideo: Psicolibro-Waslala.

Klein, A. (2004). Adolescencia, un puzzle sin modelo para armar. Montevideo: Psicolibro-Waslala.

Klein, A. (2006). Adolescentes sin adolescencia: Reflexiones sobre la construcción de subjetividad adolescente bajo el contexto neoliberal. Montevideo: Psicolibro- Universitario.

Kohut, H. (1982). Introspection, empathy and the semi-circle of mental health. International Journal of Psychoanalysis, 63, 395-407.

Lacan, J. (1979). Las formaciones del inconsciente. Buenos Aires: Nueva Visión.

Laplanche, J (1980). La sexualidad. Buenos Aires: Nueva Visión.

Laplanche, J. (1987). La cubeta. Trascendencia de la transferencia. In: Problemáticas $V$. Buenos Aires: Amorrortu.

Laplanche, J., \& Pontalis, J.B. (1981) Diccionario de Psicoanálisis. Barcelona: Labor.

Lewkowicz, I. (2004). Pensar sin estado. La subjetividad en la era de la fluidez. Buenos Aires: Paidós.

Lyons-Ruth, K. (2004). La disociación y el diálogo infantoparental: una perspectiva longitudinal a partir de la investigación sobre apego. Revista Aperturas Psicoanalíticas, 17, http://www.aperturas.org/17lyons.html.

Puget, J., \& Kaës, R. (1991). Violencia de estado y psicoanálisis. Buenos Aires: Centro Editor de América Latina.

Roudinesco, E. (2003), La familia en desorden. Buenos Aires: Fondo de la Cultura Económica de Argentina. 
Tavares, L. (1999). Os custos socias do ajuste neoliberal no Brasil. Santiago de Chile: Facultad Latinoamericana de Ciencias Sociales, Sede Chile.

Valdré, R. (1998). Experiencias psicoterapéuticas en adolescentes con toxicomanía de éxtasis. Psicoanálisis con Niños y Adolescentes, 11.

Urribarri, R. (1990). Sobre adolescencia, duelo y a posteriori. Revista Psicoanalítica Argentina, XLII(4), 179-181.

Vasconcelos, E., \& Morgado, R. (2005). Subsidios analíticos e metodológicos para a atuação no sistema único de assistência social (SUAS), e do programa de atendimento integral à familia. Brazil: PAIF/SAS/RJ.

Visor, (1999), Enciclopedias Audiovisuales. Uruguay: Author.
Volnovich, J.C. (2002). El default con nuestros hijos: La desesperación por no cobrar-El dolor de no poder pagar. Available at: www.laguiasemanal.com.ar/2002-0923/humanidades.htm.

Winnicott, D. (1972). Realidad y juego. Barcelona: Gedisa.

Winnicott, D. (1979). Escritos de pediatría y psicoanálisis. Barcelona: Laia.

Winnicott, D. (1981). El proceso de maduración en el niño. Barcelona: Laia.

Received January 16, 2007 Revision received May 29, 2007

Accepted June 21, 2007 